\title{
'That God May Have Mercy Upon All': A Review-Essay of Matthias Gockel's Barth and Schleiermacher on the Doctrine of Election
}

\author{
Jason A. Goroncy \\ PhD student; University of St Andrews, St Andrews, Scotland \\ E-mail: jgoroncy@gmail.com
}

\begin{abstract}
The doctrine of election lies at the heart of Reformed theology. This essay offers a review of Matthias Gockel's recent comparison between two of Reformed theology's greatest voices: that of Friedrich Schleiermacher and Karl Barth. Gockel outlines Schleiermacher's contribution to the doctrine before turning to consider its modifications in Barth's work. The advance of these two thinkers on this issue has significant implications for the ongoing questions of universal election and universal salvation. Consequently, the possibility of an apokatastasis panton arises naturally from their theology. This possibility is briefly explored.
\end{abstract}

\section{Keywords}

Barth, election, predestination, Schleiermacher, soteriology, universalism

Karl Barth's scolding criticisms of Friedrich Schleiermacher are no secret, and no short mileage has been made by theologians on the apparent division between the two theologians. In Matthias Gockel's latest offering (a revised version of his 2002 doctoral dissertation completed at Princeton under Bruce McCormack), he joins Robert Sherman and others in enriching, with renewed sophistication, our understanding of the relationship between Barth and Schleiermacher, challenging traditional evaluations that 'liberal theology' and 'dialectical theology' stand in irreconcilable opposition.

Rather than attempt to cover a multidimensional canvas with broad strokes, Gockel restricts his inquiry to an incisive and cogent comparison of the development of the doctrine of election in the two thinkers. Without proposing any theory of historical dependence, Gockel contends that the divergence between these two commanding Reformed theologians does not stem from 
irreconcilable starting points, but rather from the indispensability of God's grace. Gockel convincingly argues that "Barth's theology is not just a repudiation of Schleiermacher but an expansion of his predecessor's work in a new framework." ${ }^{1} \mathrm{He}$ also shows us that while the Swiss theologian's evaluation of 'the father of modern theology' is "sometimes negative, sometimes positive and often ambiguous," ${ }^{2}$ Barth was not always a reliable interpreter of his own thought, nor always consistent in his criticisms of others.

\section{Schleiermacher and the Single Divine Will}

Gockel's thesis is that the doctrine of election in Barth's early theology bears a close resemblance to Schleiermacher's own theo-centric position. Barth's theology, however, from 1936 onwards, undergoes a radical Christological revisioning of his earlier position. Gockel begins his survey and assessment of Schleiermacher by turning to Schleiermacher's revision of the doctrine in his 1819 essay, "On the Doctrine of Election."3 Gockel helpfully, albeit briefly, situates Schleiermacher's early contribution on election in the context of the ecclesiastical union between the Lutheran and Reformed churches in Prussia in 1817. Central to this union were the debates over the Lord's Supper and the doctrine of election. The crucial point over the latter concerned "the indispensability of divine grace for... conversion and the question whether human beings can accept or resist God's grace by their own free choice." ${ }^{4}$ Schleiermacher's most creative contribution to the discussion was his notion of an undivided and unconditional "single divine will and decree which effects [both] faith and unbelief." 5 He argues that the older paradigm of a twofold divine will of election and reprobation is "as meaningless as the question why God made human beings in the way they were made." ${ }^{\circ}$ The elect, Schleiermacher contends, are those who are "regenerated and begin their religious selfdevelopment." Although the remainder of persons are for now spiritually

1 Matthias Gockel, Barth and Schleiermacher on the Doctrine of Election: A SystematicTheological Comparison (Oxford: Oxford University Press, 2006), 13. Subsequent page references to this book will be in the main text.

2 Gockel, Barth and Schleiermacher, 9.

3 An earlier version of this chapter appeared as Matthias Gockel, "New Perspectives on an Old Debate: Friedrich Schleiermacher's Essay on Election," International Journal of Systematic Theology 6, no. 3 (2004), 301-18.

${ }^{4}$ Gockel, Barth and Schleiermacher, 18.

5 Gockel, Barth and Schleiermacher, 26.

${ }^{6}$ Gockel, Barth and Schleiermacher, 29.

7 Gockel, Barth and Schleiermacher, 30. 
dead and "not yet members of the kingdom of God," 8 they are included in God's love and so "they never lose the ability to be revived." Gockel notes that the notion of the single decree "emphasises the unity of the divine attributes and helps to clarify key issues not only in the debate over election but also in the doctrine of God." 10

Schleiermacher's revision of the doctrine of election, articulated in the 1819 essay, is more fully developed in his Der christliche Glaube (1821-22) within the bounds of a single divine decree of universal predestination to salvation in Christ, and systematically located in ecclesiology. Gockel notes that the starting-point of the discussion of election, for Schleiermacher, is the "dilemma that arises from the simultaneous existence of believers and non-believers, on the one hand, and the benevolent divine will towards all human beings in Christ's redemptive work, on the other hand." ${ }^{11}$ Schleiermacher's response is to insist that the "divine will is identical with the work of redemption in and through the person of Christ." 12

Schleiermacher rejects any idea of two, separate, foreordained groups of persons - a double-predestination - and the notion that one group might be eternally excluded from the benefits of Christ's work. Such ideas, he maintains, betray the general character of redemption and the universal mission of the church. God has one will, and that will is identical with who God is, and what God does in Jesus Christ. Humanity_-believers and unbelievers alike-are the object of God's predestinating will of salvation in Christ. Despite the temporary reprobation of some, "God sees all human beings, not only the believers, in Christ." ${ }^{13}$ In light of this reality, the church is called to live, order its life after, and bear universal witness to the divine decision.

Gockel concludes his examination of Schleiermacher by noting that despite Schleiermacher's Christologically motivated affirmation of general redemption and rejection of eternal reprobation, his overall construction remains theocentric: "it is grounded in the belief in God the almighty creator, even though ecclesiology is its context and christology its background." ${ }^{14}$

${ }^{8}$ Gockel, Barth and Schleiermacher, 34.

9 Gockel, Barth and Schleiermacher, 30.

${ }^{10}$ Gockel, Barth and Schleiermacher, 34.

11 Gockel, Barth and Schleiermacher, 101.

12 Gockel, Barth and Schleiermacher, 100.

${ }^{13}$ Gockel, Barth and Schleiermacher, 102.

${ }^{14}$ Gockel, Barth and Schleiermacher, 103. 


\section{Barth's Early Revision of the Doctrine of Election in his Der Römerbrief}

In his Der Römerbrief, Barth raises two objections against the Augustinian formulation, which he regards as "a 'mythologizing' construction." ${ }^{15}$ First, Barth rejects the notion that predestination can be explained in terms of cause and effect. While the human act of faith happens within a familiar historical context, its origin always lies with God: "The act of faith does not occur when a human being has recognized God but when God has recognized a human being." " Barth's point: "God wants to be known through God." ${ }^{17}$ Second, Barth discards the attribution of election and reprobation to "predetermined quantities of individual persons, since this neglects that God's eternal predestination is related to humankind as a whole and is not a one-time event but occurs time and again in history when a human being is addressed by God's Word." ${ }^{18}$ The driving issue here for Barth, as in his whole doctrine of election, is the divine freedom.

For Barth, the key verse for understanding Romans, and Christian theology, in general, is Romans 11:32, "God enclosed everyone in disobedience, in order to show mercy on everyone." This verse affirms that the content of God's predestination is God's unconditional mercy. More radically, Barth contends that Paul's claim suggests a modification - though not a rejection —of the notion of double predestination. Double predestination does not require rejection so long as we are clear that it refers to a movement, to the "teleology by which God's salvific act is directed, namely, from reprobation to election." ${ }^{19}$ For Barth, reprobation is never the goal. "God's Yes shines even into the last depth of His No, precisely because the latter is so radical, because it is the divine No." ${ }^{20}$ Reprobation exists therefore "only as the shadow of the light of election." 21

Gockel contends that there is a distinct echo of Schleiermacher's doctrine of election in Barth's own early revision of the doctrine. In Der Römerbrief, Barth accentuates the dialectical unity of God's decree: "God's reprobation (of the elect) and God's election (of the reprobate) are 'unintuitably one and the same in God.' "22 Gockel identifies two central aspects concerning the relation

15 Gockel, Barth and Schleiermacher, 108.

16 Gockel, Barth and Schleiermacher, 108.

17 Karl Barth, Der Römerbrief 1922 (Zollikon-Zurich: Evangelischer Verlag, 1954), 384. Gockel works primarily from Barth's 1922 edition where Barth's treatment of election is more extensive.

18 Gockel, Barth and Schleiermacher, 109.

19 Gockel, Barth and Schleiermacher, 113.

20 Barth, Römerbrief 1922, 387.

${ }^{21}$ Barth, Römerbrief 1922, 386.

22 Gockel, Barth and Schleiermacher, 118. 
between reprobation and election for Barth. First, the possibility of reprobation is overcome eternally in God. Adam's old world really is surpassed by Christ's new world. Second, the individual outcome of the two-fold possibility of unbelief and belief is not determined by God before time; but rather, in the freedom of God is the event in which God addresses the creature in time. The content or purpose of such an address is qualified by the "turn from reprobation to election" in God, which expresses the one eternal will of God for humanity. ${ }^{23}$ Any duality here of judgement and grace is the duality of God's unified action, an action which affects all human beings alike, and is determined by God's redemptive will revealed in Christ's death and resurrection. The church and the world, therefore, "stand under the same promise and the same judgment [which] makes it impossible to conceive them as two separate groups of persons." ${ }^{24}$ Even as early as his Romans commentary, Barth maintained a hopeful universalism grounded in the freedom and love of God leading to the priority of election over reprobation: "reprobation has been overcome and absorbed by election." ${ }^{25}$ Christ's work "entails the hope that the duality between faith and history does not preclude the possibility of an eventual restoration of humankind and a return 'into the unity with God, which is now and here completely lost.' "'26 Barth's emphasis here is that the original unity of God and humanity (a notion abandoned in the Göttingen lectures) is not superseded by judgement. Judgement, rather, is practical, leading to a re-union of human and divine righteousness.

Gockel observes that the relationship between the historical appearance of Jesus Christ and the determination of God's will remains unclear in Barth's theology, and his emphasis on the original unity leads to similar problems to Schleiermacher's notion of absolute dependence. Furthermore, when Barth "asserts that God's will is revealed in Jesus Christ who personifies God's universal faithfulness and righteousness, it remains unclear how the eternal history between God and humankind is related to the history of Jesus Christ." ${ }^{27}$

23 Barth, Römerbrief, 333.

${ }^{24}$ Gockel, Barth and Schleiermacher, 125.

25 Barth, Römerbrief, 402.

${ }^{26}$ Gockel, Barth and Schleiermacher, 130.

27 Gockel, Barth and Schleiermacher, 131. 


\section{Barth's Development of the Revision in the Göttingen Lectures}

Barth's revision of the Reformed doctrine of election is developed further in the so-called Göttingen Dogmatics, where he punctuates the teleological ordering of election and reprobation. The real purpose of God's predestinating act is always election, even in rejection. While the reprobation is real as the shadow side of election, it is never God's final word. God's final word is Jesus Christ and in him every promise of God finds its 'Yes' (2 Cor. 1:18-20). "Rejection does not take place for its own sake but in revelation of the righteousness of God in order that God's mercy might be manifested in his election, and in order that in it all, though in this irreversible order, God himself might be known and praised." ${ }^{28}$ God's judgement is never divorced from God's grace and can never be recognized apart from "the cross, the judgment, the condemnation in which we stand"; the way of predestination therefore leads us "by way of condemnation-indeed, by the way of hell itself — to salvation and life." ${ }^{29}$ We will return to this below in the discussion of Barth's Church Dogmatics II/2.

Gockel concludes his discussion of Barth's Göttingen work by surmising that Barth's doctrine of election "becomes more actualistic and less speculative, while still not christocentric." He adds, "Barth stops short of eschatological universalism, and his consistent emphasis on God's freedom as well as the assertion that 'all are at every moment under the divine Either-Or' should be taken seriously." 30

The picture that Gockel paints is that in both the Römerbrief and the Göttingen Dogmatics, Barth has developed a Schleiermacherian reconstruction of the doctrine of election by means of the idea of a single divine decree towards life. Although Schleiermacher understands the Creator-creature relationship differently from Barth, they both hold that the single divine decree is to be understood in the context of the historical decision between faith and unbelief. For both of them (at this point), the doctrine of election remains fundamentally theocentric and universal, with a focus on the graced-initiative of the divine act which involves a teleological movement in time from reprobation to election, the former serving the latter, and the latter qualifying the former. Above all, the focus for both theologians is on "the predestining God" rather than "individual predestined human beings." 31

${ }^{28}$ Karl Barth, The Göttingen Dogmatics: Instruction in the Christian Religion trans. Geoffrey W. Bromiley; Vol. 1 (Grand Rapids: Eerdmans, 1991), 460.

29 Barth, Göttingen Dogmatics, 471.

${ }^{30}$ Gockel, Barth and Schleiermacher, 155.

${ }^{31}$ Gockel, Barth and Schleiermacher, 157. 


\section{Barth's Second Modification of the Doctrine of Election}

In his fifth chapter, entitled "Barth's Christological Revolution," Gockel turns briefly to Barth's lectures of 1936 (given at two Reformed seminaries in Hungary) and 1937 (Barth's Gifford Lectures on the Scots Confession given at the University of Aberdeen), and more substantially to Barth's Church Dogmatics II/2, where Barth developed his most radical proposal, modifying for a second time his doctrine of election. In the Christological revision undertaken in II/2, election no longer refers to the twofold possibility of faith and unbelief but to the double determination of individual human beings and God's own being. Barth's priority is that God sees every human being and also himself in Christ.

Here, Gockel is on the more traversed ground of Barth's notion that Jesus Christ is both God's elect himself and the foundation of humanity's election. ${ }^{32}$ Gockel argues that it was not until the 1936 lectures that Barth's Christological revisioning of the doctrine of election first appears; that what happened for and to humanity at Golgotha and was revealed at Easter is our eternal election. It is also here that Barth identifies the one will of God in double predestination with Jesus Christ, that is, with God's own being. "Jesus Christ not only reveals but also constitutes God's gracious choice as the self-determination to be God for His people and the determination of humankind to be the people of God." 33 Barth contends that God's gracious choice is the divine decision made in Jesus Christ, the speculum electionis. ${ }^{34}$ It is in and through Jesus Christ that God has actualized his eternal covenant with humanity, God's eternal election of himself to communion with humanity, and humanity to communion with God. Here Barth distinguishes himself from the disposition in some camps of the Reformed tradition of an insistence on the inscrutableness and invisibility of the divine decrees. In Jesus Christ - the electing God and the elected Man-God's purposes in election are made manifest to all. Christ is, in Barth's words, "the first and last word to men of the faithfulness of God"

32 The same point is made by Heppe. Heinrich Heppe, Reformed Dogmatics: Set Out and Illustrated from the Sources ed. Ernst Bizer; trans. G.T. Thompson (Grand Rapids: Baker, 1950), 168. Barth used Heppe's Die Dogmatik der evangelisch-reformierten Kirche as the primary source for his Göttingen lectures. Heinrich Heppe, Die Dogmatik der evangelisch-reformierten Kirche, dargestellt und aus den Quellen belegt ed. Ernst Bizer (Neukirchen: Neukirchner Verlag, 1958).

${ }_{33}$ Gockel, Barth and Schleiermacher, 169.

${ }^{34}$ Karl Barth, Church Dogmatics II.2 ed. G.W. Bromiley and T.F. Torrance; trans. G.W. Bromiley et al. (Edinburgh: T\&T Clark, 1957), 64. Here Barth echoes Calvin who insists that "Christ [is] ... the mirror wherein we must, and without self-deception may, contemplate our own election." John Calvin, Institutes of the Christian Religion, ed. John T. McNeill; trans. Ford Lewis Battles; 2 Vols. (Philadelphia: The Westminster Press, 1977), III.24.5. 
in election. ${ }^{35}$ Jesus Christ, therefore, is not merely the channel of God's one decree, but its source. And he is not merely the one who elects, but he is also the one who elects himself to be the modus operandi by which others are elected.

\section{Consequences of Barth's Revision}

Gockel turns to critically consider the consequences of Barth's doctrine of election. He identifies six key areas: (1) epistemological implications, (2) the concrete determination of predestination, (3) the issue of double predestination, (4) the actuality of predestination, (5) the question of universal election and universal salvation, and (6) the relation between Israel and the Christian church. I will focus here on (2), (3), (4), and (5).

\section{The Concrete Determination of Predestination}

Regarding the second area (i.e., on the concrete determination of predestination), while Barth never intended to drive a wedge between the economy and being of God, Gockel sides with McCormack over against Molnar that this very inconsistency arises within Barth's own formulation of his doctrine of election: "The assumption of a divine will preceding the predestination puts into doubt whether the gracious choice really belongs to God's 'own eternal essence." "36 The issue fundamentally concerns whether or not the works of God ad extra are the overflow of the works of God ad intra or whether the one eternal will of God is identical with Jesus Christ ensarkos. McCormack contends that "election is an eternal decision and as such resists our attempts to temporalize it." To do so, he argues, is to introduce into the being of God in pre-temporal eternity a 'before' and an 'after.' "If election is an eternal decision," McCormack argues, "then it has never not taken place." ${ }^{37}$ Molnar's response is that such a move makes election a "necessity" and, consequently, "the very opposite of what Barth intended with his doctrine of the immanent

${ }^{35}$ Karl Barth, The Epistle to the Romans, trans. E.C. Hoskyns (Oxford: Oxford University Press, 1968), 105.

36 Gockel, Barth and Schleiermacher, 179.

37 Bruce L. McCormack, "Grace and Being: The Role of God's Gracious Election in Karl Barth's Theological Ontology," in The Cambridge Companion to Karl Barth ed. John Webster (Cambridge: Cambridge University Press, 2000), 101. 
Trinity." ${ }^{38}$ Molnar's reading of Barth's proposal that God has one being, and that that one being subsists simultaneously in two different forms (the second dependent on the first), which are not separate but, rather, are a unity-indistinction and distinction-in-unity, is under-attended by Gockel.

\section{Jesus the Reprobate—-Joyous News"}

On the question of double predestination, Gockel rehearses Barth's conviction that we must speak of Jesus Christ not only in reference to the positive side of election, but also in reference to the other side of God's decree-reprobation. Here, as we shall see below, Barth sets himself apart from the tradition (or at least extends the tradition) and declares that both election and reprobation happen in Jesus Christ. Barth's doctrine of reprobation is as Christological as his doctrine of election. He contends that the God who elected fellowship with humanity also elected our rejection. In electing our rejection, however, "He made it his own. He bore it and suffered it with all its most bitter consequences." 39 Thus in the self-reprobation of Godself in Jesus Christ-the Man justified and the 'Judge judged in our place'-humanity recognizes not only God's final 'Yes' but also its own reprobation. This self-giving is God's free choice and entails God's self-determination and the determination of humanity through a 'wonderful exchange' in Jesus Christ. "To believe in God's predestination," Gockel concludes, "means by definition to believe in the nonreprobation of humankind." ${ }^{40}$ As Barth notes, "in God's eternal purpose” it is not humanity, but "God Himself who is rejected in His Son." ${ }^{11}$ God's selfgiving in Jesus Christ consists in the fact that he is rejected in our place: "Predestination means that from all eternity God has determined upon man's acquittal at His own cost." ${ }^{\prime 2}$ Gockel then raises the question and apparent

${ }^{38}$ Paul D. Molnar, Divine Freedom and the Doctrine of the Immanent Trinity: In Dialogue with Karl Barth and Contemporary Theology (Edinburgh: T\&T Clark, 2002), 62. The important debate between McCormack's and Molnar's reading of Barth's doctrine of election is beyond the scope of this essay. Those wishing to follow that discussion should consult McCormack's essay "Grace and Being" and Molnar's Divine Freedom and the Doctrine of the Immanent Trinity. For more recent discussion, see Bruce L. McCormack, "Seek God where he may be found: a response to Edwin Chr. van Driel," Scottish Journal of Theology 60 (2007), 62-79; Paul D. Molnar, "Can the Electing God be God without us? Some Implications of Bruce McCormack's Understanding of Barth's Doctrine of Election for the Doctrine of the Trinity," Neue Zeitschrift für Systematische Theologie und Religionsphilosophie 49, no. 2 (2007), 199-222.

39 Barth, CD II/2, 164.

40 Gockel, Barth and Schleiermacher, 181.

${ }^{41}$ Barth, CD II/2, 167.

42 Barth, CD II/2, 167. 
conflict concerning whether the claim that the Son of God instead of the Son of Man suffered God's wrath contrasts with Barth's earlier claim that "the elected human being Jesus is the target or 'offering' of God's wrath." He notes Barth's own awareness of and answer to this in II/1: "Only God Himself could bear God's wrath. Only God's mercy was capable of bearing the kind of suffering to which the creature existing in opposition to God is subject. Only God's mercy could be touched by this suffering in such a way that it knew how to make it its own suffering. And only God's mercy was strong enough not to perish in this suffering." ${ }^{43}$ As if hell-that is, something of creation-could exhaust the awful shame and scandal of sin.

Barth's concern in his treatment on election is that election should be good news-gospel-or, what Barth calls is another place, "joyous news." ${ }^{44}$ Thus does Barth open his chapter on election in II/2: "The doctrine of election is the sum of the Gospel because of all words that can be said or heard it is the best; that God elects man; that God is for man too the One who loves in freedom... Its function is to bear basic testimony to eternal, free and unchanging grace as the beginning of all the ways and works of God." ${ }^{45}$ Here Barth is following Calvin — and, according to Muller, the Reformed tradition more generally at least up until 1650 - who repeatedly stressed that we look to Christ as the assurance of our election. ${ }^{46}$ Calvin is as adamant as Barth. Where Calvin - and the Reformed tradition-is silent, however, is about how the question of reprobation - the shadow side of election-also relates to Christ. Holmes has suggested that the weakness in Calvin's account of predestination is not that election is separate from Christ (which it is not), but that "the doctrine of reprobation is detached, Christless and hidden in the unsearchable purposes of God. As such it bears no comparison with the doctrine of election, but remains something less than a Christian doctrine." ${ }^{47}$ Holmes goes on to suggest that Calvin's shortcoming is not that he reserved an equal stature-a

43 Gockel, Barth and Schleiermacher, 183.

${ }_{44}$ Karl Barth, God Here and Now, trans. Paul M. van Buren (London: Routledge \& Kegan Paul, 1964), 29.

45 Barth, CD II/2, 3.

46 Richard A. Muller, Christ and the Decree: Christology and Predestination in Reformed Theology from Calvin to Perkins (Durham: Labyrinth Press, 1986). I am grateful to Stephen Holmes for pointing me to Muller's book. Stephen R. Holmes, Listening to the Past: The Place of Tradition in Theology (Carlisle/Grand Rapids: Paternoster/Baker, 2002), 124-6. Holmes concludes his survey by stating that "the Reformed Orthodox doctrine of election simply cannot be accused of a failure to be Christological." Holmes, Listening, 128.

47 Holmes, Listening, 129. 
double decree-to God's 'Yes' and 'No' in election, but that he has "almost no room for the doctrine of reprobation in his account"; "the 'No' does not really enter his thinking," thus leading to an asymmetry between the two decrees and so, as Holmes suggests, "fails to be gospel." ${ }^{48}$ This contrasts with Barth's Christological theology of reprobation. Holmes summarizes Barth's position thus:

In willing to be gracious in the particular way God in fact wills to be gracious, the Incarnation of the Divine Son, there is both a 'Yes' and a 'No', election and reprobation. God elects for humanity life, salvation, forgiveness, hope; for himself he elects death, perdition, even, as the Creed has said, hell. This self-reprobation of God is indeed the primary referent of the doctrine of election, in that God's determination of himself is formally if not materially more basic than his determination of the creature, and so is considered first by Barth. In the eternal election of grace, which is to say in Jesus Christ, God surrenders his own impassibility, embraces the darkness that he was without—and indeed impervious to- - until he willed that it should be otherwise... The apostle put it more succinctly: "He became sin for us." This is the full content of the divine judgement, of the 'No' that is spoken over the evil of the world and of human beings. God elects for himself the consequences of that ' $\mathrm{No}$ ', in saying 'Yes' to, that is, in electing, us. That is the whole content of the double decree, the whole content of the 'Yes' and the 'No' that God pronounces as one word, the whole content the election of grace. ${ }^{49}$

Concerned that his own tradition had at this point replaced Jesus Christ with a decretum absolutum, Barth asked, "Is it a fact that there is no other basis of election outside Jesus Christ? Must the doctrine as such be related to this basis and this basis only?" ${ }^{50}$ Because of Jesus Christ, Barth was able to speak of God's 'No' as gospel also.

\section{The Actuality of Predestination}

On the actuality of predestination, Gockel questions how useful Barth's grammar regarding predestination as a present event is. He suggests that God's "eternally preceding" decision is "the mystery of all historical events," 51 and that it does not have to imply a continuation of the decision itself within history, given God's predestining election of Jesus Christ. Gockel helpfully suggests that "a less actualistic view of predestination could more clearly emphasize

48 Holmes, Listening, 130; cf. p. 134.

49 Holmes, Listening, 132.

50 Barth, CD II/2, 63.

${ }^{51}$ Gockel, Barth and Schleiermacher, 185. 
the significance of the historical appearance of Jesus Christ and thus dispel the impression that Barth tears apart the 'eternal content' and the 'temporal form' of election." 52

\section{Universal Election and Universal Salvation}

Brewing away throughout Gockel's book, not infrequently rearing its head, is the question of universal election and universal salvation. Gockel contends that Barth's Christological revision leads him to abandon his 1936 objection to universalism and affirmation of an eschatological division between the elect and the reprobate. Barth now "joins Schleiermacher in leaving open the possibility of a 'final opening up and expansion of the circle of election and calling' which may include everyone." ${ }^{3}$ Barth's reluctance, however, to embrace universalism leads to some pointed challenges by Gockel.

Gockel notes that both Schleiermacher and Barth share a stance consistent with supralapsarianism's claim that the decree of predestination precedes that of creation and fall, although they both go further in their assertion that God's mercy is the decisive criterion not of redemption only but also of predestination. Gockel argues that despite Barth's "own explicit unwillingness to go that far," that is, to embrace a universal predestination to salvation, his affirmation of universal election "implies some form of universal salvation."

Gockel also contends that Barth's appeal to God's freedom is, at this point, inconsistent with Barth's own position regarding God's self-determination to be Immanuel in Jesus Christ. Gockel notes that Barth's (and Schleiermacher's) caution on the issue can be partly explained by the fact that "any affirmation of universalism would have meant the endorsement of an ecumenical heresy, which could have cost him dearly." ${ }^{55}$ However, the question remains: How can that which has already been overcome in Jesus Christ ever be undone? How can this impossible possibility remain? Gockel suggests that Schleiermacher is at least more consistent here with his emphasis on the unity of God's will. With all of Barth's massively powerful Christological revisioning, he, according to Gockel, "shied away from certain far-ranging implications." "One should ask," Gockel suggests, "whether a consistent theory of an Apokatastasis, far from presenting a danger or even a threat, might not be a more satisfying 
option than the claim that the New Testament leaves us with a paradoxical constellation of the 'universalism of the divine salvific will' versus the 'particularism of judgment." "57

\section{The Hope for an apokatastasis panton}

Many commentators have suggested that Barth's reluctance to embrace with certainty an apokatastasis panton, even while holding out hope for such reconciliation is compelling. Barth insists that God's grace is characterized by God's freedom. This means not only that we must never impose limits on the scope of grace, but also that we must never impose an universalist 'system' on grace either. To embrace either option would be to compromise the freedom of grace, and also to presume that we can define the precise scope of God's grace. That is why Barth's theology of grace incorporates a dialectical protest: he protests both against a system of universalism and against a denial of universalism. ${ }^{58}$ The essential point, for Barth, is that God's grace is completely free; that when God acts in grace it is none other than God himself who acts in freedom. When God comes to us in his grace, therefore, we can be certain that no third party or shadowy motive is twisting his arm. Because of this divine freedom and because of the nature of divine grace as grace, we can neither deny nor affirm, therefore, the possibility of universal salvation. We stand to confess with Abraham, "Shall not the Judge of all the earth do right?"59 Barth writes:

The proclamation of the Church must make allowance for this freedom of grace. Apokatastasis Panton? No, for a grace which automatically would ultimately have to embrace each and every one would certainly not be free grace. It surely would not be God's grace. But would it be God's free grace if we could absolutely deny that it could do that? Has Christ been sacrificed only for our sins? Has He not, according to 1 John $2: 2$, been sacrificed for the whole world?... [Thus] the freedom of grace is preserved on both these sides... Even in the midst of hell, grace would still be grace, and even in the midst of hell it would have to be honored and praised and therefore announced to the other inhabitants of hell. It is not free for nothing, but it is also not grace for nothing. We should certainly not know it if we were of the opinion that we could stop short of announcing it. ${ }^{60}$

57 Gockel, Barth and Schleiermacher, 208.

58 See Oliver Crisp, “On Barth's Denial of Universalism,” Themelios 29 (2003), 18-29.

59 Gen. 18:25.

${ }^{60}$ Barth, God Here and Now, 34, 35. The implications of Barth's doctrine expressed in this book are teased out by Berkouwer who maintains that Barth stands at the very "threshold of the apokatastasis" but turns away because of "the freedom, the gift of grace." It is thus "gift-character of grace" which is undermined by universalism: "The error of universalism does not lie in glorying 
It is difficult to imagine a more solid basis for an apokatastasis panton than Barth provides in his doctrine of election and reprobation. But does Barth's commitment to divine freedom contradict the center of his Christological revision? Does he ultimately lead us all to a country and then not promise us that we might enter? Gockel, following Janowski, suggests he does, and that the payment for such a commitment threatens to "tear open again, though in a modified way, the abyss of the decretum absolutum et horribile" ${ }^{61}$ —as though God's Word towards a person might be different from that which he has spoken in Jesus Christ.

While Gockel notes Barth's denial of an ultimate apokatastasis panton, he joins a pantheon of critiques - sympathetic and otherwise - who see an inconsistency in Barth here. Consider, for example, the critique from Bromiley. As one of the editors and principal translators of Barth's work, few are more familiar with Barth's corpus and theology than Bromiley. Citing IV/3, $\$ 70.2$, Bromiley synopsises Barth view: "The lie cannot overthrow the truth, but God may finally condemn the liar to live in it." ${ }^{\prime 2}$ Bromiley observes in Barth a "trend toward an ultimate universalism" although acknowledges that, for Barth, "universalism in the sense of the salvation of all individuals is not a necessary implicate of Barth's Christological universalism." ${ }^{63} \mathrm{He}$ suggests that Barth's reservation here is "not really adequate." ${ }^{44}$ Gockel identifies the same inconsistency in Barth, a holding back of the full consequences of Barth's Christology. Again, Bromiley notes, "God's manifest purpose in Christ is to save, but under the sovereignty of the Spirit some might not be saved. The question is whether the Christological reference finally helps or matters very much. Is not the ultimate decision still taken apart from the revealed election-that is, not in the prior counsel of the Father but in the inscrutable operation of the Spirit? In other words, the decision regarding individuals is simply removed from the inscrutability of sovereign predetermination to the inscrutability of sovereign calling." ${ }^{35}$

in God's grace, but in integrating grace into a system of conclusions which is in conflict with grace as a sovereign gift." Gerrit C. Berkouwer, The Triumph of Grace in the Theology of Karl Barth, trans. Harry R. Boer (Grand Rapids: Eerdmans, 1956), 362.

${ }^{61}$ Gockel, Barth and Schleiermacher, 210.

62 Geoffrey W. Bromiley, "Karl Barth," in Creative Minds in Contemporary Theology, ed. Philip Edgcumbe Hughes (Grand Rapids: Eerdmans, 1966), 49.

63 Bromiley, "Karl Barth," 54.

64 Bromiley, "Karl Barth," 54.

65 Bromiley, "Karl Barth," 53. 
The only two tenable positions available for the soteriological question are either (i) a robust reaffirmation of limited atonement (the negative side of which includes the possibility of annihilation), or (ii) some form of Christological universalism (with varying degress of dogmaticism). Barth, of course, was correctly suspicious of 'isms,' whether universalism or any other -ism, and would not affirm a dogmatic doctrine of universal salvation, although he does join a tradition of both Eastern and Western theologians going back to Origen of Alexandria (185-232), Clement of Alexandria (d. 215), Gregory of Nyssa (335-394?), Ambrose of Milan (337?-397) and Gregory of Nazianzus (329389) who all affirm a strong hope in universal salvation. Barth famously concludes IV/3/1 by again urging that we have no good reason why we should be forbidden, or forbid ourselves from an "openness to the possibility that in the reality of God and man in Jesus Christ there is contained much more than we might expect," including the "unexpected withdrawal of that final threat." 66 Barth continues:

If for a moment we accept the unfalsified truth of the reality which even now so forcefully limits the perverted human situation, does it not point plainly in the direction of the work of a truly eternal divine patience and deliverance and therefore of an apokatastasis or universal reconciliation? If we are certainly forbidden to count on this as though we had a claim to it, as though it were not supremely the work of God to which man can have no possible claim, we are surely commanded the more definitely to hope and pray for it as we may do already on this side of this final possibility, i.e., to hope and pray cautiously and yet distinctly that, in spite of everything which may seem quite conclusively to proclaim the opposite, His compassion should not fail, and that in accordance with His mercy which is 'new every morning' He 'will not cast off for ever' (La. 3:22f., 31). ${ }^{67}$

The creature cannot impose anything upon God because God is sovereign and free. That is why universalism, Barth pressed, equals the elimination of God's freedom. But if God in his sovereignty and freedom has revealed himself in his being-in-act - that is, in Jesus Christ — then ought this not have radical implications for all doctrinal issues, and no less this one. One such implication is that it cannot be presumed that God in his total freedom will act other than he has acted in Jesus Christ-full of grace and truth.

${ }^{66}$ Karl Barth, Church Dogmatics IV.3.1, ed. G.W. Bromiley and T.F. Torrance; trans. G.W. Bromiley (Edinburgh: T\&T Clark, 1999), 477-8.

${ }_{67}$ Barth, CD IV/3/1, 478. 
Therefore, we may reasonably hope for a full apokatastasis. Few have expressed this hope more boldly than the nineteenth-century Congregationalist minister James Baldwin Brown: "The love which won the sceptre on Calvary will wield it as a power, waxing ever, waning never, through all the ages; and that the Father will never cease from yearning over the prodigals, and Christ will never cease from seeking the lost, while one knee remains stubborn before the name of Jesus, and one heart is unmastered by His love." ${ }^{68}$ Or consider these words from Thomas Erskine:

I cannot believe that any human being can be beyond the reach of God's grace and the sanctifying power of His Spirit. And if all are within His reach, is it possible to suppose that He will allow any to remain unsanctified? Is not the love revealed in Jesus Christ a love unlimited, unbounded, which will not leave undone anything which love could desire? It was surely nothing else than the complete and universal triumph of that love which Paul was contemplating when he cried out, 'Oh the depth of the riches both of the wisdom and knowledge of God!' ${ }^{6}$

In Jesus Christ, the Triune God has bound humanity to himself in such a way that even if we refuse him and damn ourselves to hell, God in his love will never cease hunting us down. So even if the church cannot affirm dogmatically the apokatastasis panton, we can hope for it, pray for it, and stop denying the possibility of it in the grace of God. As von Balthasar asserts, there is all the difference in the world between believing in the certitude of universal salvation and hoping for it. ${ }^{70}$

In answering the question, 'Will, then, all people be saved in the end?', Braaten reminds us that "We do not already know the answer. The final answer is stored up in the mystery of God's own future. All he has let us know in advance is that he will judge the world according to the measure of his grace and love made known in Jesus Christ, which is ultimately greater than the fierceness of his wrath or the hideousness of our sin." ${ }^{71}$ So Barth noted in The Humanity of God: "This much is certain, that we have no theological right to set any sort of limits to the loving-kindness of God which has appeared in Jesus

${ }^{68}$ James Baldwin Brown, The Doctrine of Annihilation in the Light of the Gospel of Love (London: Henry S. King \& Co., 1875), 118-9.

69 William Hanna, ed., Letters of Thomas Erskine of Linlathen, 3 ed. (Edinburgh: David Douglas, 1878), 428.

70 See Hans Urs von Balthasar, Dare We Hope "That All Men Be Saved"? With a Short Discourse on Hell (Fort Collins: Ignatius Press, 1988).

${ }^{71}$ Carl E. Braaten, Principles of Lutheran Theology (Augsburg: Fortress, 1983), 84. 
Christ. Our theological duty is to see and understand it as being still greater than we had seen before." ${ }^{2}$

\section{A Concluding Appreciation}

The criticisms and their implications raised by Gockel will no doubt continue to be a point of dispute - a dialectic_-among readers of Barth for the foreseeable future. Those with an interest in the more general debate about universalism would be well served by reading Gockel's fine study. However, those who are already convinced that Schleiermacher's and (early) Barth's doctrine of election remains the most tenable proposal will only find further material here to bolster their conviction. To those who remain unconvinced, Gockel offers little argument here to change one's mind.

Gockel's work fills a notable gap in Schleiermacher and Barth studies. While there is, encouragingly, something of a renaissance of interest in Schleiermacher, Gockel's contribution to our understanding of, and appreciation for, Schleiermacher's project in general, and his doctrine of election in particular, is thus far unsurpassed. Schleiermacher is not an easy read. Not only is his own terminology inconsistent, but his grammar and theological geography remain largely foreign to contemporary readers. Gockel offers some assistance here. Also, his contribution regarding Barth's early thinking on election serves as a most worthy conversation partner with other contributions in the same area. ${ }^{73}$

The book is clearly written, avoids stereotypes of Schleiermacher and Barth, and includes a useful bibliography and two indexes. While Gockel offers a very valuable survey of the thinking of two Protestant giants on a central theme not only in their theology, but in the Reformed tradition of which they were both heirs - a valuable task in itself-I would have liked to have seen more critical engagement with these two voices. It may have also been fruitful, for example, to chart how Schleiermacher's and Barth's doctrine of election relates to the human response to God's free grace in baptism, for example, as Barth was already directing us to in IV/4.

That said, in what is certainly one of the finest studies to have appeared on Barth in recent years, Gockel models the kind of close dogmatic scrutiny that Schleiermacher's and Barth's theological contributions both deserve and

${ }^{72}$ Karl Barth, The Humanity of God, trans. John Newton Thomas and Thomas Wieser (London: Collins, 1961), 62.

${ }^{73}$ For example, Suzanne McDonald, "Barth's 'Other' Doctrine of Election in the Church Dogmatics," International Journal of Systematic Theology 9, no. 2 (2007), 134-47. 
demand. Those with an interest in systematic theology and the history of doctrine, those with an interest in getting their mind around Barth's much misunderstood doctrine of election, those with an interest in exploring a way forward for overcoming old rifts between Lutherans and Calvinists, and those with an interest in more current debates over universalism will benefit from reading Gockel's book. 